\title{
Kinerja Pelaksana Manajemen Informasi Kesehatan di Lingkungan Dinas Kesehatan Kabupaten Bondowoso
}

\author{
Nanthyan Khampa Usada, Artha Prabawa \\ Departemen Biostatistika dan Kependudukan, Fakultas Kesehatan Masyarakat, \\ Universitas Indonesia
}

*Korespondensi: Nanthyan Khampa Usada - nanthyankhampa@gmail.com

\begin{abstract}
Abstrak
Sistem manajemen dan informasi kesehatan merupakan komponen yang berfokus pada terwujudnya sistem kesehatan yang berdaya guna dan berhasil guna secara efektif dan efisien. Pentingnya tujuan tersebut menjadi dasar aturan bahwa setiap fasilitas pelayanan kesehatan berkewajiban dalam menyelenggarakan Sistem Informasi Kesehatan (SIK) demi membantu tercapainya sasaran pembangunan kesehatan. Penelitian ini bertujuan menganalisis determinan kinerja pelaksana manajemen sistem informasi kesehatan di lingkungan Dinas Kesehatan Kabupaten Bondowoso. Merupakan penelitian kuantitatif dengan pendekatan sistem menggunakan metode cross sectional. Kuesioner online dengan google form disebarkan melalui whatsapp group terhadap sampel penelitian yaitu seluruh (111 responden) pelaksana manajemen sistem informasi kesehatan di 25 puskesmas. Hasil menunjukkan responden berkinerja baik 55,0\%. Menggunakan uji Chi-Square faktor input yang berpengaruh signifikan $(\mathrm{p}<0,05)$ terhadap output berupa kinerja adalah usia, pendidikan terakhir, keterampilan, pengetahuan, dan sarana prasarana.
\end{abstract}

Kata kunci: kinerja, manajemen sistem informasi kesehatan, dinas kesehatan

\section{Performance of Health Information Management Implementers in the Bondowoso District Health Office}

\begin{abstract}
The health information and management system is a component that focuses on the realization of an effective and effective health system that is effective and efficient. The importance of this goal forms the basis for the rule that every health service facility is obliged to organize a Health Information System (SIK) in order to help achieve health development goals. This study aims to analyze the performance determinants of human resources of health information system management in primary health care centre in the Bondowoso Departement of Health district.. This is a quantitative research with a systems approach using a cross sectional method. An online questionnaire using google form was distributed via whatsapp group to the sample of this study are all of human resources of health information system management in primary health care centre (111 respondents). The results showed that the respondents performed well 55.0\%. Using the Chi-Square test, the input factors that have a significant effect $(p<0.05)$ on the output in the form of performance are age, last education, skills, knowledge, and infrastructure. Keywords: performance, health information system management, district health office
\end{abstract}




\section{PENDAHULUAN}

Komponen penting dalam Sistem Kesehatan Nasional (SKN) salah satunya adalah sistem manajemen dan informasi kesehatan (1,2). Manajemen sistem informasi kesehatan yang efektif sekurangkurangnya mencakup sistem informasi di fasilitas pelayanan kesehatan (puskesmas dan jaringannya) sebagai fasilitas kesehatan tingkat pertama, sistem informasi di rumah sakit sebagai fasilitas kesehatan tingkat rujukan, sistem informasi di dinas kesehatan kabupaten/kota/provinsi, sistem informasi di Kementerian Kesehatan serta sistem informasi di lintas sektor (3).

Penyediaan data dan informasi kesehatan yang tepat, akurat dan handal diperlukan guna membuat laporan dan keputusan baik di internal puskesmas untuk peningkatan pelayanan, pengembangan program-program yang dibutuhkan untuk masyarakat, maupun penyusunan kebijakan di tingkat dinas kesehatan kabupaten/kota atau jenjang diatasnya. Berlandaskan dari pentingnya pengelolaan rekam medis tersebut, tenaga yang mengelola rekam medis memiliki peran yang sangat krusial dalam menghasilkan data dan informasi kesehatan yang berkualitas (4).

Laporan Kementerian PPN menyatakan bahwa standar kualifikasi Sumber Daya Manusia (SDM) manajemen informasi kesehatan menjadi salah satu penyebab tidak optimalnya SIK di
Indonesia. Keadaan SDM SIK di Indonesia ini menunjukkan gambaran yang hampir sama baik di pusat maupun daerah. Kuantitas SDM masih belum dapat memenuhi kebutuhan, sedangkan kualitas atau kemampuan masih kurang (3).

Keadaan dan keterbatasan SDM ini terjadi pula di puskesmas lingkungan dinas kesehatan Kabupaten Bondowoso. Peraturan Menteri Pendayagunaan Aparatur Negara dan Reformasi Birokrasi RI Nomor 30 Tahun 2013, menetapkan kebutuhan perekam medis di puskesmas adalah 5 SDM terampil dan 2 SDM ahli (6), sedangkan di lingkungan dinas kesehatan Kabupaten Bondowoso, tidak terdapat satupun dari 25 puskesmas yang memenuhi standar minimal tersebut.

Berkaitan dengan kompetensi yang salah satunya adalah latar belakang pendidikan, ini menjadi hal yang perlu dikaji apakah latar belakang pendidikan dapat mempengaruhi kinerja yang dihasilkan. Mendukung premis tersebut, Peraturan Menteri Kesehatan RI Nomor 43 Tahun 2019 mewajibkan diselenggarakannya kredensial di lingkungan puskesmas guna memastikan bahwa setiap pelayanan kesehatan dilakukan oleh tenaga yang kompeten agar mutu pelayanan kesehatan terjamin (7).

Pengelolaan data di dinas kesehatan Kabupaten Bondowoso masih belum optimal dengan ditemukannya 
inkonsistensi data dan keterlambatan pengumpulan oleh puskesmas ke dinas kesehatan sebagai permasalahan utama yang krusial dalam kaitannya dengan kualitas informasi atau laporan yang dihasilkan.

Sedangkan ketepatan waktu merupakan salah satu indikator kinerja yang baik, sekaligus menjadi standar data berkualitas karena masih relevan dengan keadaan. Maka determinan kinerja pelaksana manajemen sistem informasi kesehatan yang bertugas sebagai pengelola rekam medis dan informasi puskesmas di lingkungan dinas kesehatan Kabupaten Bondowoso menjadi hal penting untuk dikaji.

Sumber daya manusia merupakan komponen kompleks dalam organisasi, kontribusinya menjadi penentu ketercapaian tujuan sehingga dibutuhkan sistem dengan elemen yang saling terkait dalam pengelolaannya. Pendekatan sistem pada manajemen sumber daya manusia menjadi pemecahan masalah kompleksitas tersebut (8).

Perilaku sumber daya manusia dapat timbul dikarenakan terdapat sebab yang mendasari dan tujuan yang diarahkan. Perilaku dan prestasi individu dapat secara langsung dipengaruhi oleh variabel yang dikelompokkan menjadi tiga komponen yaitu individu, psikologis dan keorganisasian. Pemahaman dan memaksimalkan tiga variabel tersebut dapat menghasilkan prestasi yang diharapkan, kinerja yang sesuai dengan tugas-tugas yang perlu diselesaikan, dan mendukung pencapaian sasaran suatu pekerjaan yang dikehendaki $(9,10)$.

Kompetensi sumber daya manusia sebagai karakteristik atau kepribadian dalam individu yang memprediksi cara berperilaku, cara berpikir dan memiliki hubungan kusal dengan kinerja individu, sehingga dapat menjadi referensi penilaian kriteria kinerja. Spencer and Spencer (1993) mengidentifikasi lima kompetensi yang mendasari karakteristik yaitu motives, traits, self concept, knowledge dan skills $(8,9,11)$.

Penelitian terwujud dari tiga teori pokok yaitu teori perilaku dan prestasi Gibson, Ivancevich and Donnely (1991) serta teori kompetensi Spencer and Spencer (1993) dengan pendekatan sistem (system approach) Hariandja (2002). Teori ini menjadi dasar penarikan variabel independen input terdiri dari faktor individu (usia, masa kerja, pendidikan terakhir), faktor kompetensi (pengetahuan, keterampilan) dan faktor organisasi (sarana prasarana dan imbalan). Sedangkan variabel dependen output adalah kinerja pelaksana manajemen sistem informasi kesehatan puskesmas di lingkungan dinas kesehatan Kabupaten Bondowoso $(8,9,11)$. 


\section{METODE}

Penelitian ini merupakan penelitian kuantitatif survei analitik cross sectional yang berarti penelitian dilakukan guna mempelajari dinamika korelasi antara faktor dengan efek menggunakan survei atau pengumpulan data sekaligus pada suatu waktu (12).

Pelaksana manajemen sistem informasi kesehatan yang berada di lingkungan Dinas Kesehatan Kabupaten Bondowoso sangat terbatas sehingga purposive sampling digunakan sebagai teknik pengambilan seluruh sampel yaitu 111 pelaksana manajemen sistem informasi kesehatan yang berperan dalam menjalankan kegiatan pelayanan rekam medis di 25 puskesmas yang berada di lingkungan Dinas Kesehatan Kabupaten Bondowoso. Sampel yang terdiri dari 57 petugas pendaftaran, 26 petugas SP2TP, dan 28 petugas pelaporan rawat inap menjadi responden untuk mendapatkan data primer melalui kuesioner online Google Form yang disebarkan pada 3 WhatsApp group milik Dinas Kesehatan.

Kuesioner disusun secara sistematis berpedoman pada standar pelaksanaan rekam medis dan penelitian terdahulu yang dimodifikasi berdasarkan pokok pikiran penelitian. Uji kuesioner menggunakan pearson correlation dan korelasi biseral menunjukkan pertanyaan valid, sedangkan nilai Cronbach Alpha menunjukkan bahwa pertanyaan pada kuesioner telah reliabel.

Analisis univariat mendeskripsikan karakteristik setiap variabel melalui distribusi frekuensi dan persentase. Variabel pengetahuan dan keterampilan tiap jawaban benar diberi bobot 3, faktor sarana prasarana dan imbalan tiap jawaban mendukung diberi bobot 1 , sedangkan pada faktor output kinerja, jawaban tidak pernah diberi bobot 1, kadang diberi bobot 2, sering diberi bobot 3 dan selalu diberi bobot 4. Analisis Bivariat menggunakan uji Chisquare dengan software statistic untuk melihat ada atau tidaknya hubungan antara variabel independen input (usia, masa kerja, pendidikan terakhir, keterampilan, pengetahuan, sarana prasarana dan imbalan) dengan variabel dependen output yaitu kinerja pelaksana manajemen sistem informasi kesehatan puskesmas.

\section{HASIL}

Berdasarkan lima tahap yang dikemukakan pada teori perkembangan karir menurut Donald Super (1980), hanya terdapat tiga kelompok usia pada penelitian ini yaitu usia $<24$ tahun (exploration), usia 25 - 44 tahun (estabilihsment) dan usia 45 - 64 tahun (maintenance). Sedangkan kelompok usia $0-14$ tahun (growth) dan usia >65 tahun (decline) tidak ditemukan diantara responden penelitian. Distribusi 
usia responden mayoritas adalah kelompok estabilihsment (25 - 44 tahun) yaitu $72,1 \%$.

Terdapat hubungan signifikan antara usia dengan kinerja pelaksana manajemen sistem informasi kesehatan puskesmas di lingkungan Dinas Kesehatan Kabupaten Bondowoso (p-value 0,002). Kelompok usia 25 - 44 tahun (OR 2,8) berarti responden dengan kelompok usia tahap estabilihsment memiliki peluang 2,8 kali lebih besar dibandingkan dengan kelompok usia $<24$ tahun atau tahap exploration. Sedangkan kelompok usia 45 - 64 tahun $(\mathrm{OR} 0,47)$ artinya responden kelompok usia tahap maintenance memiliki peluang 0,47 kali lebih besar dibandingkan dengan kelompok usia $<24$ tahun.

Distribusi masa kerja pelaksana manajemen sistem informasi kesehatan tidak terdapat perbedaan yang besar antara responden yang bekerja kurang dari 3 tahun $(52,3 \%)$ dan yang telah bekerja lebih dari 3 tahun (47,7\%). Hasil uji Chi Square menunjukkan nilai $p$-value 0,198 yang berarti tidak terdapat hubungan signifikan antara masa kerja dengan kejadian kinerja pelaksana manajemen sistem informasi kesehatan puskesmas di lingkungan Dinas Kesehatan Kabupaten Bondowoso.

Distribusi jenjang pendidikan responden hampir sama antara pelaksana manajemen informasi kesehatan yang memiliki pendidikan terakhir SMA dan Sarjana. Masing-masing berurutan adalah
45 orang $(40,5 \%)$ yang memiliki pendidikan terakhir SMA, 42 orang $(37,8 \%)$ yang berpendidikan terakhir S1/S2 dan pendidikan terakhir DIII dengan jumlah pelaksana manajemen informasi kesehatan paling sedikit yaitu 24 orang $(21,6 \%)$.

Terdapat hubungan signifikan antara pendidikan terakhir dengan kinerja ( $p$-value 0,0005). Nilai OR 7.39 untuk pendidikan DIII artinya responden dengan pendidikan terakhir DIII memiliki peluang 7,39 kali lebih besar dibandingkan dengan responden dengan pendidikan terakhir SMA. Sedangkan S1/S2 menunjukkan angka (OR 6.2) berarti bahwa responden dengan pendidikan terakhir S1/S2 memiliki peluang 6,2 kali lebih besar dibandingkan dengan yang pendidikan terakhirnya SMA.

Pelaksana manajemen sistem informasi kesehatan puskesmas yang memiliki pengetahuan kurang $(56,8 \%)$ lebih banyak dibandingkan dengan yang memiliki pengetahuan baik (43,2\%). Hasil analisis bivariat menunjukkan hanya 20 responden $(31,7 \%)$ yang memiliki pengetahuan kurang, memiliki kinerja baik.

Pengetahuan kurang paling banyak diantara pelaksana manajemen sistem informasi kesehatan puskesmas adalah pada bidang kerja pelaporan rawat inap $(78,6 \%)$ selanjutnya oleh bidang kerja SP2TP $(65,4 \%)$ dan petugas pendaftaran (42,1\%). Jika hasil dilihat dari jumlah responden, petugas pendaftaran merupakan 
bidang kerja yang memiliki paling banyak responden dengan pengetahuan kurang yaitu 24 responden.

Distribusi jawaban terkait pengetahuan bidang kerja pendaftaran dengan skor rendah paling banyak adalah tentang kerahasiaan dokumen dan isi rekam medis $(61,4 \%)$. Sedangkan pada bidang kerja SP2TP, distribusi jawaban responden dengan skor rendah paling banyak adalah terkait sistem pencatatan puskesmas $(65,4 \%)$. Distribusi jawaban responden dengan skor rendah paling banyak adalah pada pertanyaan tentang pengelolaan data rawat inap $(82,1 \%)$.

Nilai $p$-value adalah 0,0005 berarti terdapat perbedaan proporsi kejadian kinerja baik antara responden yang berpengetahuan baik dengan responden yang berpengetahuan kurang. Sedangkan (OR 12,6) yang artinya pelaksana manajemen sistem informasi kesehatan puskesmas yang berpengetahuan baik memiliki peluang 12,6 kali lebih tinggi untuk menghasilkan kinerja yang baik dibanding dengan yang berpengetahuan kurang.

Tingkat keterampilan pelaksana manajemen sistem informasi kesehatan puskesmas hampir seimbang yaitu 53 orang memiliki keterampilan kurang $(47,7 \%)$ dan 58 orang memiliki keterampilan yang baik $(52,3 \%)$. Sedangkan keterampilan kurang paling banyak diantara pelaksana manajemen sistem informasi kesehatan puskesmas adalah pada bidang kerja SP2TP $(73,1 \%)$ disusul oleh bidang kerja pelaporan rawat inap $(46,4 \%)$ dan petugas pendaftaran $(36,8 \%)$.

Distribusi jawaban terkait keterampilan bidang kerja pendaftaran dengan skor rendah paling tinggi adalah tentang retensi dokumen rekam medis $(86,0 \%)$. Sedangkan pada bidang kerja SP2TP, adalah terkait pengumpulan laporan puskesmas kepada Dinas Kesehatan Kabupaten Bondowoso $(69,2 \%)$. Jawaban petugas pelaporan rawat inap juga menunjukkan hasil serupa yaitu terkait keterampilan dalam mengumpulkan laporan rawat inap puskesmas kepada Dinas Kesehatan Kabupaten Bondowoso sesuai dengan tanggal yang ditetapkan $(57,1 \%)$.

Analisis hubungan antara keterampilan dengan kinerja didapatkan hanya sebanyak 23 responden $(43,4 \%)$ yang memiliki keterampilan kurang, menghasilkan kinerja baik. Sedangkan diantara responden yang memiliki keterampilan baik, 38 responden $(65,5 \%)$ menghasilkan kinerja baik. p-value 0,032 berarti ada hubungan signifikan antara keterampilan dengan kinerja. Nilai (OR 2,48) artinya responden yang memiliki keterampilan baik 2,48 kali lebih tinggi mempunyai peluang untuk menghasilkan 
kinerja baik dibanding responden dengan keterampilan kurang.

Responden yang merasa bahwa sarana dan prasarana di puskesmasnya telah memadai, terdapat 40 responden $(83,3 \%)$ yang memiliki kinerja baik. Didpatkan nilai p-value 0,0005 dan (OR 10) yang artinya adalah jika sarana dan prasarana di puskesmas memadai dalam pelaksanaan manajemen sistem informasi kesehatan puskesmas, maka peluang pegawai menghasilkan kinerja baik adalah 10 kali lebih besar dibandingkan dengan yang sarana dan prasarananya kurang memadai.

Berlandaskan pada standar sarana prasarana Peraturan Menteri Kesehatan nomor 31 tahun 2019, sarana prasarana yang paling banyak tidak tersedia di puskesmas lingkungan Dinas Kesehatan Kabupaten Bondowoso adalah Local Area Network (LAN) dan aplikasi khusus, yaitu sebanyak 77 responden $(69,4 \%)$ menyatakan tidak terdapat LAN dan 68 responden $(61,3 \%)$ menyatakan tidak terdapat aplikasi untuk mendukung pekerjaannya.

Kepuasan terhadap imbalan yang didapatkan sebagai pelaksana manajemen sistem informasi kesehatan puskesmas menunjukkan gambaran yang hampir sama antara responden yang kurang puas $(50,5 \%)$ dan yang telah puas $(49,5 \%)$ terhadap gaji atau jasa pelayanan yang diterima. Hasil uji Chi-square diperoleh nilai p-value 0,385 maka dapat disimpulkan bahwa pada penelitian ini tidak terdapat perbedaan proporsi kejadian kinerja baik antara responden yang memiliki kepuasan terhadap imbalan dengan responden yang tidak merasakan puas terhadap imbalan yang diberikan.

Tabel 1. Distribusi Pelaksana Manajemen Sistem Informasi Kesehatan Puskesmas Menurut Faktor Risiko dan Kinerja di Lingkungan Dinas Kesehatan Kabupaten Bondowoso Tahun 2021

\begin{tabular}{|c|c|c|c|c|c|c|c|c|}
\hline \multirow{3}{*}{ Faktor Risiko } & \multicolumn{4}{|c|}{ Kinerja } & \multirow{2}{*}{\multicolumn{2}{|c|}{ Total }} & \multirow{3}{*}{ OR $(95 \%$ CI $)$} & \multirow{3}{*}{ P Value } \\
\hline & \multicolumn{2}{|c|}{ Kurang } & \multicolumn{2}{|c|}{ Baik } & & & & \\
\hline & $\mathbf{n}$ & $\%$ & n & $\%$ & $\mathbf{n}$ & $\%$ & & \\
\hline \multicolumn{9}{|l|}{ Usia } \\
\hline$<24$ tahun & 6 & 60,0 & 4 & 40,0 & 10 & 100 & 1.000 & \multirow{3}{*}{0,002} \\
\hline $25-44$ tahun & 28 & 35,0 & 52 & 65,0 & 80 & 100 & $2,786(0,73-10,7)$ & \\
\hline $45-64$ tahun & 16 & 76,2 & 5 & 23,8 & 21 & 100 & $0,469(0,093-2,36)$ & \\
\hline \multicolumn{9}{|l|}{ Masa Kerja } \\
\hline$\leq 3$ tahun & 30 & 51,7 & 28 & 48,3 & 58 & 100 & 1,768 & \multirow{2}{*}{0,198} \\
\hline$>3$ tahun & 20 & 37,7 & 33 & 62,3 & 53 & 100 & $(0,83-3,78)$ & \\
\hline \multicolumn{9}{|l|}{ Jenjang Pendidikan } \\
\hline SMA & 32 & 71,1 & 13 & 28,9 & 45 & 100 & 1.000 & \multirow{3}{*}{0,0005} \\
\hline DIII & 6 & 25,0 & 18 & 75,0 & 24 & 100 & $7.385(2,394-22,782)$ & \\
\hline $\mathrm{S} 1 / \mathrm{S} 2$ & 12 & 28,6 & 30 & 71,4 & 42 & 100 & $6.154(6,154-15,587)$ & \\
\hline \multicolumn{9}{|l|}{ Pengetahuan } \\
\hline Kurang & 43 & 68,3 & 20 & 31,7 & 63 & 100 & 12,593 & \multirow{2}{*}{0,0005} \\
\hline Baik & 7 & 14,6 & 41 & 85,4 & 48 & 100 & $(4,82-32,93)$ & \\
\hline \multicolumn{9}{|l|}{ Keterampilan } \\
\hline Kurang & 30 & 56,6 & 23 & 43,4 & 53 & 100 & 2,478 & \multirow{2}{*}{0,032} \\
\hline Baik & 20 & 34,5 & 38 & 65,5 & 58 & 100 & $(1,15-5,34)$ & \\
\hline
\end{tabular}




\begin{tabular}{|c|c|c|c|c|c|c|c|c|}
\hline \multirow{3}{*}{ Faktor Risiko } & \multicolumn{4}{|c|}{ Kinerja } & \multirow{2}{*}{\multicolumn{2}{|c|}{ Total }} & \multirow{3}{*}{ OR $(95 \% \mathrm{CI})$} & \multirow{3}{*}{ P Value } \\
\hline & \multicolumn{2}{|c|}{ Kurang } & \multicolumn{2}{|c|}{ Baik } & & & & \\
\hline & $\mathbf{n}$ & $\%$ & $\mathbf{n}$ & $\%$ & $\mathbf{n}$ & $\%$ & & \\
\hline \multicolumn{9}{|l|}{ Sarana dan Prasarana } \\
\hline Kurang memadai & 42 & 66,7 & 21 & 33,3 & 63 & 100 & 10,00 & \multirow{2}{*}{0,0005} \\
\hline Memadai & 8 & 16,7 & 40 & 83,3 & 48 & 100 & $(3,98-25,15)$ & \\
\hline \multicolumn{9}{|l|}{ Imbalan } \\
\hline Kurang puas & 28 & 50,0 & 28 & 50,0 & 56 & 100 & 1,500 & \multirow{3}{*}{0,385} \\
\hline Puas & 22 & 40,0 & 33 & 60,0 & 55 & 100 & $(0,71-3,18)$ & \\
\hline Jumlah & 50 & 45,0 & 61 & 55,0 & 111 & 100 & & \\
\hline
\end{tabular}

Tabel 2. Kinerja Pelaksana Manajemen Sistem Informasi Kesehatan Puskesmas di Lingkungan Dinas Kesehatan Kabupaten Bondowoso Tahun 2021

\begin{tabular}{lcc}
\hline \multicolumn{1}{c}{ Kinerja } & Jumlah & Persentase \\
\hline Kurang & 50 & 45,0 \\
Baik & 61 & 55,0 \\
$\quad$ Total & 111 & 100 \\
\hline
\end{tabular}

Pelaksana manajemen sistem informasi kesehatan puskesmas di lingkungan Dinas Kesehatan Kabupaten Bondowoso yang berkinerja kurang dan berkinerja baik tidak memiliki jumlah yang jauh berbeda. 50 responden $(45,0 \%)$ berkinerja kurang dan dengan jumlah yang sedikit lebih banyak yaitu 61 responden $(55,0 \%)$ memiliki kinerja yang baik.

Distribusi kinerja kurang paling banyak diantara pelaksana manajemen sistem informasi kesehatan puskesmas adalah petugas pelaporan rawat inap $(57,1 \%)$ selanjutnya bidang kerja SP2TP $(50,0 \%)$. Sedangkan hasil berdasarkan jumlah responden, petugas pendaftaran merupakan bidang kerja yang memiliki paling banyak responden dengan kinerja kurang yaitu 21 responden $(36,8 \%)$.
Tabel 3. Distribusi Kinerja Berdasarkan Bidang Kerja Pelaksana Manajemen Sistem Informasi Kesehatan Puskesmas di Lingkungan Dinas Kesehatan Kabupaten Bondowoso Tahun 2021

\begin{tabular}{lcccccc}
\hline \multirow{2}{*}{$\begin{array}{c}\text { Bidang } \\
\text { Kerja }\end{array}$} & \multicolumn{4}{c}{ Kinerja } & \multicolumn{2}{c}{ Total } \\
\cline { 2 - 6 } & \multicolumn{2}{c}{ Kurang } & \multicolumn{2}{c}{ Baik } & \multicolumn{2}{c}{} \\
\cline { 2 - 7 } & $\mathbf{n}$ & $\mathbf{\%}$ & $\mathbf{n}$ & $\mathbf{\%}$ & $\mathbf{n}$ & $\mathbf{\%}$ \\
\hline Pendaftaran & 21 & 36,8 & 36 & 63,2 & 57 & 100 \\
SP2TP & 13 & 50,0 & 13 & 50,0 & 26 & 100 \\
Pelaporan & 16 & 57,1 & 12 & 42,9 & 28 & 100 \\
Rawat Inap & 16 & & & & & \\
\hline
\end{tabular}

Penilaian kinerja dikelompokkan menjadi enam dimensi menurut Bernadin and Russel (1998). Dimensi tersebut adalah quality, quantity, timeliness, costeffectiveness, need for supervision dan interpersonal impact. Hasil analisis menunjukkan total skor dan atau persentase dari enam dimensi tersebut tidak memiliki perbedaan angka yang bermakna. Masing masing berurutan adalah quantity (kuantitas) dengan jumlah skor tertinggi yaitu 1322 (19,72\%), selanjutnya quality (kualitas) dengan skor 1216 (18,14\%), timeliness (ketepatan waktu) 1175 (17,53\%), interpersonal impact 1033 (15,41\%) cost-effectiveness 1008 (15,04\%), dan skor terendah need for supervision 947 $(14,13 \%)$. 


\section{PEMBAHASAN}

Keterbatasan penelitian ini adalah hanya dilaksanakan di puskesmas di lingkungan Dinas Kesehatan Kabupaten Bondowoso, sebagai Kabupaten yang memiliki kondisi dan khasnya sendiri, sehingga hasil penelitian mengenai kinerja pelaksana manajemen sistem informasi kesehatan ini tidak dapat digeneralisasikan diseluruh kabupaten. Keterbatasan lain adalah pada tahap pengumpulan data. Kuesioner disebarkan menggunakan sistem online melalui group Whatsapp yang dimiliki oleh Dinas Kesehatan Kabupaten Bondowoso, namun terdapat beberapa responden yang tidak masuk dalam group Whatsapp tersebut sehingga untuk mengatasinya peneliti mencari kontak dan mengirimkan pesan secara pribadi kepada responden yang bersangkutan.

Kinerja pelaksana manajemen informasi kesehatan yang berperan dalam menjalankan kegiatan pelayanan rekam medis puskesmas di lingkungan Dinas Kesehatan Kabupaten Bondowoso. Analisis berdasarkan enam dimensi penilaian kinerja menurut Bernadin and Russel (13) menunjukkan bahwa jumlah paling tinggi adalah dimensi quantity $(19,72 \%)$ dan dimensi dengan nilai paling rendah adalah need for supervision $(14,13 \%)$. Hal ini berarti kuantitas kinerja yang dihasilkan telah baik sedangkan dalam prosesnya masih dibutuhkan supervisi atau bimbingan dari atasan dan atau rekan kerja. Variabel kinerja dikategorikan menjadi 2 kelompok yaitu kinerja kurang jika nilai mean kurang dari sama dengan 60,37, dan kinerja baik jika nilai mean lebih dari 60,37.

Berdasarkan pengkategorian tersebut, didapatkan hasil bahwa pelaksana manajemen sistem informasi kesehatan puskesmas di lingkungan Dinas Kesehatan Kabupaten Bondowoso yang berkinerja kurang dan berkinerja baik tidak memiliki jumlah yang jauh berbeda, masing masing yaitu 50 responden $(45,0 \%)$ berkinerja kurang dan dengan jumlah yang sedikit lebih banyak yaitu 61 responden $(55,0 \%)$ memiliki kinerja yang baik. Hal ini berarti bahwa kinerja pelaksana manajemen informasi kesehatan puskesmas di lingkungan Dinas Kesehatan Kabupaten Bondowoso sudah cukup baik dan hanya perlu beberapa upaya untuk meningkatkan kinerja pada dimensi yang dinilai kurang.

Berkaitan dengan pandemi COVID19 yang masih berlangsung saat penelitian ini dilakukan, kinerja pelaksana manajemen sistem informasi kesehatan menjadi sangat penting karena pencatatan dan pelaporan secara tidak langsung dapat mengendalikan angka kematian atau insiden penyakit COVID-19. Berdasarkan peta sebaran COVID-19 yang dikelola oleh Komite Penanganan COVID-19 dan Pemulihan Ekonomi Nasional (KPCPEN), tercatat dari 2.832.755 kasus yang terkonfirmasi 
COVID-19, hanya sebanyak 4.880 data yang tersedia menyebutkan komorbid pasien, tercantum $99,8 \%$ tidak terdata atau tidak memiliki kondisi penyerta. Hal ini berarti pencatatan terkait komorbid yang diderita oleh pasien belum lengkap, sedangkan komorbid menjadi penyebab terbanyak kematian pasien COVID-19 (14).

Oleh karena itu peran pelaksana manajemen sistem informasi kesehatan menjadi sangat penting karena jika pencatatan telah dilakukan dengan baik, pencegahan pasien komorbid untuk terinfeksi hingga pemberian vaksin dan penanganan pasien yang terinfeksi dapat segera diberi penanganan dan dikendalikan.

Hasil penelitian menunjukkan peluang paling tinggi dalam menghasilkan kinerja baik adalah responden pada tahap estabilihsment (25 - 44 tahun). Tahap estabilihsment adalah saat individu memasuki level pengembangan diri dengan ambisi meningkatkan posisi melalui peningkatan keterampilan dari pengalaman kerja. Sedangkan pada tahap maintenance (45 - 64 tahun), individu lebih berfokus pada mempertahankan pola pekerjaannya dan mulai menemukan kekhawatiran dalam mempertahankan pekerjaannya karena persaingan dengan rekan kerja yang lebih muda (15).

Pernyataan tersebut sejalan dengan hasil penelitian ini yang menunjukkan bahwa distribusi kinerja baik paling sedikit terdapat pada tahap maintenance $(45-64$ tahun). Penelitian yang menunjukkan hasil serupa adalah penelitian (16) yang mendapatkan hasil signifikan dengan korelasi berpola negatif, yaitu bahwa semakin tua usia pegawai maka semakin rendah kinerja yang dihasilkan.

Perkembangan teknologi dapat pula menjadi salah satu faktor bahwa usia yang lebih muda lebih mudah menguasai penggunaan teknologi dibandingkan usia yang lebih tua, hal ini juga dikemukakan oleh (17) bahwa meski terdapat sejumlah kualitas positif yang dimiliki oleh pegawai yang lebih tua seperti pengalaman, etika kerja, dan komitmen, tetapi pegawai yang lebih tua dinilai kurang fleksibel dan sulit untuk menerima dan menggunakan teknologi baru.

Masa kerja pada penelitian ini adalah lama waktu responden bekerja sebagai pelaksana manajemen sistem informasi kesehatan di puskesmas. Hasil uji statistik menunjukkan bahwa tidak terdapat hubungan yang signifikan antara masa kerja dan kinerja. Hal ini sejalan dengan penelitian terdahulu yang memiliki cut off poin yang sama dengan penelitian ini yaitu 3 tahun (p-value 1,00) (18).

Analisis terkait pendidikan terakhir menunjukkan hasil semakin tinggi pendidikan terakhir yang ditempuh oleh pelaksana manajemen sistem informasi kesehatan, maka semakin tinggi pula 
peluang untuk menghasilkan kinerja yang baik. Ditemukan banyak penelitian terdahulu yang menunjukkan hasil sejalan dengan penelitian ini $(16,19-22)$.

Analisis bivariat menunjukkan hasil bahwa pelaksana manajemen sistem informasi kesehatan puskesmas yang berpengetahuan baik akan berkinerja lebih baik dibandingkan dengan yang memiliki pengetahuan kurang. Hasil ini sejalan dengan penelitian multivariat (23) yang menunjukkan bahwa pengetahuan merupakan faktor yang pengaruhnya paling besar terhadap kinerja. Hasil serupa juga ditemukan pada penelitian terdahulu $(24,25)$.

Keterampilan adalah kecakapan yang berhubungan dengan tugas yang dimiliki dan dipergunakan oleh seseorang pada waktu yang tepat (9). Analisis bivariat menunjukkan $p$-value 0,032 dan (OR 2,48) artinya pelaksana manajemen sistem informasi kesehatan puskesmas yang memiliki keterampilan baik, 2,48 kali lebih tinggi mempunyai peluang untuk menghasilkan kinerja yang baik dibanding pelaksana manajemen sistem informasi kesehatan puskesmas yang memiliki kinerja kurang.

Analisis bivariat menunjukkan adanya hubungan signifikan antara sarana dan prasarana dengan kinerja pelaksana manajemen sistem informasi kesehatan puskesmas di lingkungan dinas kesehatan
Kabupaten Bondowoso. Sarana dan prasarana yang memadai dalam pelaksanaan manajemen sistem informasi kesehatan puskesmas memberikan 10 kali peluang lebih besar untuk pegawai menghasilkan kinerja baik dibandingkan dengan yang sarana dan prasarana di puskesmasnya kurang memadai. Hasil penelitian ini sejalan dengan beberapa penelitian sebelumnya (26-28).

Hasil uji Chi-square menunjukkan nilai $p$-value 0,385 berarti tidak terdapat hubungan antara responden yang memiliki kepuasan terhadap imbalan dengan responden yang tidak merasakan puas terhadap imbalan yang diberikan. Hasil ini juga didapatkan oleh penelitian terdahulu yang menunjukkan tidak terdapat perbedaan proporsi antara imbalan dengan kinerja (p-value 0,445) (29).

\section{KESIMPULAN}

Sebanyak $\quad 56,8 \% \quad$ memiliki pengetahuan kurang, dan persentase paling tinggi pada bidang kerja pelaporan rawat inap tentang pengelolaan data. 47,7\% memiliki keterampilan kurang dengan persentase paling tinggi pada bidang kerja SP2TP terkait kedisiplinan pengumpulan laporan. Sarana prasarana yang kurang memadai $(56,8 \%)$ di puskesmas adalah local area network dan aplikasi yang mendukung. Sedangkan terdapat 50,5\% yang kurang puas terhadap imbalan. 
Input faktor individu yang berhubungan signifikan dengan kinerja pelaksana manajemen sistem informasi kesehatan puskesmas di lingkungan Dinas Kesehatan Kabupaten Bondowoso adalah usia dan pendidikan terakhir. Input faktor kompetensi yang berhubungan signifikan dengan kinerja pelaksana manajemen sistem informasi kesehatan puskesmas di lingkungan Dinas Kesehatan Kabupaten Bondowoso adalah pengetahuan dan keterampilan. Input faktor organisasi yang berhubungan signifikan dengan kinerja pelaksana manajemen sistem informasi kesehatan puskesmas di lingkungan Dinas Kesehatan Kabupaten Bondowoso adalah sarana dan prasarana. Output kinerja pelaksana manajemen sistem informasi kesehatan puskesmas di lingkungan Dinas Kesehatan Kabupaten Bondowoso baik dengan persentase $55,0 \%$.

Rekomendasi aplikatif yang dapat dirumuskan diantaranya adalah untuk meningkatkan pengetahuan dan keterampilan dengan menyediakan pelatihan dan atau seminar berkala bagi pelaksana manajemen sistem informasi kesehatan terkait pengelolaan data bagi petugas pelaporan rawat inap dan keterampilan petugas SP2TP terkait kedisiplinan pengumpulan laporan. Pengadaan sarana dan prasarana yang merata bagi seluruh puskesmas khususnya jaringan LAN, aplikasi pendukung pelaksanaan manajemen sistem informasi kesehatan dan jaringan internet yang memadai dapat menjadi bahan masukan kepada Bagian perencanaan Dinas Kesehatan. Rendahnya persentase dimensi need for supervision dapat menjadi rekomendasi kepada Bidang pelayanan kesehatan untuk menegakkan aturan dengan memberikan sistem reward dan punishment bagi pelaksana manajemen sistem informasi kesehatan yang memiliki kinerja baik atau kurang..

\section{UCAPAN TERIMA KASIH}

Kepada seluruh pihak Dinas Kesehatan Kabupaten Bondowoso yang telah memberikan izin serta seluruh pelaksana manajemen sistem informasi puskesmas yang bersedia membantu dalam usaha memperoleh data, peneliti ucapkan banyak terima kasih.

\section{DAFTAR PUSTAKA}

1. Kesehatan Kementerian Kesehatan Republik Indonesia. Keputusan Menteri Kesehatan Republik Indonesia Nomor 377/MENKES/SK/III/2007 Tentang Profesi Perekam Medis Dan informasi kesehatan. Kesehatan Kementerian Kesehatan Republik Indonesia. Jakarta; 2007. p. 7.

2. Kementrian Kesehatan Republik Indonesia. Peraturan Menteri Kesehatan Republik Indonesia Nomor 
46 Tahun 2014 tentang Sistem

Informasi Kesehatan. Jakarta:

Kementrian Kesehatan Republik

Indonesia; 2014. p. 1-66.

3. Kementrian Kesehatan Republik

Indonesia. Peraturan Menteri nomor

97 tahun 2015 tentang Peta Jalan

Sistem Informasi Kesehatan Tahun

2015-2019. Jakarta: Kementerian

Kesehatan Republik Indonesia; 2015.

4. Hosizah, Adriani L. Sistem Informasi

Kesehatan: Biostatistik Deskriptif.

Jakarta: Pusat Pendidikan SDM

Kesehatan; 2017. 148-162 p.

5. Kementerian PPN. Sumber Daya Manusia Kesehatan. Jakarta:

Kementerian Perencanaan

Pembangunan Nasional; 2019.

6. Kementerian Pendayagunaan Aparatur Negara dan Reformasi Birokrasi

Republik Indonesia. Peraturan Menteri

Pendayagunaan Aparatur Negara dan

Reformasi Birokrasi Republik

Indonesia Nomor 30 Tahun 2013

Tentang Jabatan Fungsional Perekam

Medis dan Angka Kreditnya. Vol. 53.

Jakarta: Kementerian Pendayagunaan

Aparatur Negara dan Reformasi

Birokrasi Republik Indonesia; 2013. p. 287.

7. Kemenkes RI. Peraturan Menteri nomor 43 tahun 2019 tentang Pusat Kesehatan Masyarakat. Menteri Kesehatan Republik Indonesia 2019 p.
2004-6.

8. Hariandja. Manajemen sumber daya manusia. Jakarta: Grasindo; 2002.

9. Gibson JL, Ivancevich JM, Donnelly JHJ. Organisasi, perilaku, struktur, proses. 5th ed. Adiarni N, Saputra L, editors. Jakarta: Erlangga; 1991.

10. Gibson JL, Ivancevich JM, Donnelly JHJ, Konopaske R. Organizations: behavior, structure, processes. 14th ed. New York: McGraw-Hill; 2012. 148$162 \mathrm{p}$.

11. Spencer M L, Spencer M S. Competence at work: models for superior performance. New York, USA: John Wiley \& Sons, Inc; 1993.

12. Gahayu SA. Metodologi penelitian kesehatan masyarakat. Yogyakarta: Deepublish; 2015.

13. Bernardin HJ, Russell JE. Human resources management : an experiental approach. Singapore: McGraw-Hill; 1998.

14. Kementrian Kesehatan Republik Indonesia. Keselamatan tenaga kesehatan keselamatan kita semua. Kementrian Kesehatan Republik Indonesia. 2020.

15. Super ED. A Life-Span, Life-Space Approach to Career Development. Vocat Behav. 1980;16:282-98.

16. Rahmawati P. Analisis Kinerja Pegawai Kantor DInas Kesehatan Kabupaten Bintan Provinsi Kepulauan 
Riau Tahun 2012. Universitas Indonesia; 2012.

17. Robbins SP, Coulter M. Manajemen. Sabran B, Putera DB, editors. Jakarta: Erlangga; 2009.

18. Asmara A. Determinan kinerja perawat pencegahan dan pengendalian infeksi/ Infection Prevention and Control Nurse (IPCN) Indonesia. Universitas Indonesia; 2019.

19. Hadinata D, Wahyuni S, Putri DIN. Hubungan pendidikan dan pelatihan dengan kinerja rsud cideres kabupaten majalengka. J Kesehat. 2019;5(10):112.

20. Danang Sudarso Widya Prakoso Joyo W, Holik A, Nur Iska L. Efek Usia dan Tingkat Pendidikan terhadap Kinerja Tenaga Bantu Penyuluh. J Penyul. 2021;17(1):52-9.

21. Aswad HN, Ferrial E. Pengaruh Tingkat Pendidikan, Pelatihan dan Kompensasi Terhadap Kinerja Perawat di Rumah Sakit UIT Makassar. Management. 2016;1(2):413-25.

22. Kambuaya HG, Rompas S, Rivelino SH. Hubungan Tingkat Pendidikan Dan Lamanya Kerja Dengan Kinerja Perawat di Rumah Sakit Umum Kabupaten Sorong. Keperawatan. 2016;4(1):103 - 110.

23. Harsono, Widjanarko B, Prabamurti PN. Pengaruh Tingkat Pengetahuan
Terhadap Kinerja Tenaga Kontrak Promotor Kesehatan Dalam Pelayanan Promosi Kesehatan Puskesmas Di Kabupaten Indramayu. Kesehatan. 2018;6(1):14-30.

24. Andhika Debora M S. Gambaran faktor-faktor yang berhubungan dengan kinerja pegawai instalasi laboratorium klinik RSUP Fatmawati 2012. Universitas Indonesia; 2012.

25. Fauziah SM, Rumana NA, Dewi DR, Indawati L. Kinerja Petugas Rekam Medis di Rumah Sakit Bhakti Mulia Tahun 2019. Indones Heal Inf Manag J. 2020;8(2):53-8.

26. Zainaro MA. Pengaruh sarana prasarana, pendidikan dan masa kerja perawat terhadap kepuasan kerja dan kinerja perawat ruang rawat inap rsud dr. A. Dadi Tjokrodipo Bandar Lampung. Kesehatan. 2017;11(1):1-4.

27. Ni Made Dewi Kansa P. Peran semangat kerja memediasi pengaruh lingkungan kerja terhadap kinerja pegawai dinas kesehatan kabupaten tabanan, bali. Management. 2019;1(2):60-76.

28. Ritonga ZA, Mansuri I. Evaluasi Pelaksanaan Program Sistem Pencatatan. J Ilm Perekam dan Inf Kesehat Imelda. 2017;2(2):292-306.

29. Murty WA, Hudiwinarsih G. Pengaruh Kompensasi, Motivasi Dan Komitmen Organisasional Terhadap Kinerja 
Karyawan Bagian Akuntansi (Studi

Kasus Pada Perusahaan Manufaktur Di

Surabaya). Indones Account Rev.

2012;2(02):215. 